Buana Sains Vol 19 No 1 : 61-68, 2019

\title{
PENGGUNAAN PROBIOTIK KOMBINASI lactococcus lactis DAN Lactobacillus acidophilus SEBAGAI PENGGANTI ANTIBIOTIKA PADA AYAM PETELUR YANG DIINFEKSI Escherichia coli TERHADAP ANALISIS USAHA
}

\author{
Hana Cipka Pramuda Wardhani ${ }^{1}$, W. P Lokapirnasari ${ }^{2}$ dan K. Soepranianondo ${ }^{2}$ \\ ${ }^{1}$ Program Studi Agribisnis Veteriner, Universitas Airlangga \\ ${ }^{2}$ Departemen Peternakan Veteriner, Universitas Airlangga
}

\begin{abstract}
Escherichia coli is a normal flora in the digestive system of laying hens that are non-pathogenic, which can change into pathogens and cause the egg production to decrease. So the combination of Lactococcus lactis and Lactobacillus acidophilus probiotics is expected to be able to overcome E. coli and become a substitute for the antibiotics (Virginiamycin) in animal feed. This study aims to determine business analysis including Break Event Points (BEP), Revenue Cost Ratio (R / C Ratio), Payback Period (PP) and Return On Investment (ROI). The best results obtained for the calculation of Break Event Point (BEP) on a0b2 treatment with a BEP of Rp. 17,587,24 with BEP production on a1b2 of 14,36 kg, Revenue Cost Ratio (R / C Ratio) generates a value of 1,543 for treatment a0b2, Payback Period (PP) generates a value of 1 year 3 months 9 days and Return On Investment (ROI) generates a value of 3 . It was concluded that the a0b2 treatment had good results to be developed.
\end{abstract}

Keywords: Antibiotic; business analysis; Eschericia coli; Lactococcus lactis; Lactobacillus acidophilus.

\section{Pendahuluan}

Kebutuhan protein hewani yang terdapat pada daging ayam dan telur membuat ayam banyak digemari karena harga yang masih terjangkau untuk masyarakat. Meningkatnya permintaan telur mengakibatkan peternak memilih jalan keluar untuk memberikan antibiotika yang dicampur pada pakan yang berujuan untuk mempercepat pertumbuhan dan tidak mudah sakit. Kerugian karena bakteri patogen sering menyebabkan produksi telur menurun, sehingga peternak lebih sering memberikan antibiotika (Jamin, dkk., 2015). Efek pemberian antibiotika menyebabkan residu yang mengendap pada organ ayam yang mengakibatkan resistensi antibiotika tertentu pada ternak dan bahkan pada konsumen (Barton, 2000).

Pemberian probiotik diharap mampu menggantikan peran antibiotika. Probiotik merupakan makanan tambahan berupa sel-sel mikroba hidup yang memiliki pengaruh menguntungkan bagi inang serta manusia yang akan mengkonsumsinya (Supriatna, dkk., 2016). Probiotik mampu meningkatkan kecernaan ternak sehingga ternak mampu menyerap nutrisi pada pakan secara optimal, sehingga kebutuhan produksi terpenuhi dan kebutuhan tubuh juga terpenuhi (Subekti dan Hastuti, 2015). 
H. C. P. Wardhani, W. P. Lokapirnasari, K. Soepranianondo/ Buana Sains Vol 19 No 1 : 61-68

Probiotik yang digunakan adalah Lactococcus lactis yang mampu menghasilkan asam laktat lebih cepat dibandingkan dengan bateri asam laktat lainnya yang bertugas menekan pertubuhan bakteri patogen seperti Escherichia coli (Nuryhev et al., 2016). Lactobacillus acidophilus merupakan salah satu bahan campuran untuk pembuatan produk fermentasi yang baik untuk kesehatan saluran pencernaan, dan juga rongga mulut. Lactobacillus acidophilus juga mampu meningkatkan manfaat karbohidrat (Pertami dkk.,2013).

\section{Metode Penelitian}

Sampel yang digunakan dalam penelitian ini adalah 120 ekor ayam petelur dari salah satu peternakan di desa Talun Kecamatan Montong Kabupaten Tuban, dikumpulkan dari November 2018 - Desember 2018. Data yang diperoleh pada hari terakhir penelitian diolah menggunakan Microsoft Excel kemudian dilanjutkan dengan dianalisis statistik menggunakan Analysis of Variance (ANOVA). untuk mengetahui apakah terdapat perbedaan nyata pada perlakuan $(\mathrm{P}<0,05)$ dan sangat nyata $(\mathrm{P}<0,01)$ lalu dilanjutkan dengan Uji Jarak Berganda Duncan. Alat yang digunakan dalam penelitian ini adalah timbangan digital dengan kapasitas $5 \mathrm{~kg}$ dengan ketelitian $0,01 \mathrm{~kg}$, termometer ruangan, bygrometer, kandang baterry, tempat pakan, tempat minum dan penampung telur. Bahan penelitian antibiotika (Virginiamycin) probiotik Lactococcus lactis, Probiotik Lactobacillus acidophilus, desinfektan benzalkonium chloride 10\%, air bebas chlorine, hewan coba ayam petelur umur 23 minggu pakan pabrik (tanpa antibiotika), dan bakateri E. coli.

Tabel 1. Perlakuan penggunaan probiotik kombinasi lactococcus lactis dan lactobacillus acidophilus sebagai pengganti antibiotika pada ayam petelur.

Pembagian Kelompok Dengan Faktorial

\begin{tabular}{ccccc}
\hline & $\begin{array}{c}\text { Escherichia } \\
\text { coli }\end{array}$ & \multicolumn{2}{c}{ Faktor 2 (b) } \\
\hline & & $\begin{array}{c}\text { Kontrol } \\
\text { (b0) }\end{array}$ & $\begin{array}{c}\text { Antibiotika } \\
\text { (b1) }\end{array}$ & $\begin{array}{c}\text { Probiotik Lactococcus } \\
\text { lactis 0,5\% Lactobacillus } \\
\text { Faktor 1 }\end{array}$ \\
\cline { 2 - 5 } (a) & & & & acidophilus 0,5\% (b2) \\
\cline { 2 - 5 } & Tidak (a0) & a0b0 & a0b1 & a0b2 \\
& Infeksi (a1) & a1b0 & a1b1 & a1b2 \\
\hline
\end{tabular}

Keterangan :

a0b0 : Kontrol tidak diinfeksi E. coli

a1b0 : Kontrol diinfeksi E. coli

a0b1 : 0,1\% dari berat pakan antibiotika Virginiamycin

a1b1 : 0,1\% dari berat pakan antibiotika Virginiamycin + Infeksi E. coli

a0b2 : 0,5\% dari konsumsi pakan Lactococcus lactis dan 0.5\% dari konsumsi pakan Lactobacillus acidophilus

a1b2 : 0,5\% dari konsumsi pakan Lactococcus lactis dan $0.5 \%$ dari konsumsi pakan Lactobacillus acidophilus + Infeksi E. coli

\section{Persiapan Infeksi Escherichia coli}

Dosis bakteri E. coli $10^{8} \mathrm{CFU} / \mathrm{ml}$ spesifik Avian Pathogenic Eschericibia Coli (APEC). Diberikan kepada 3 perlakuan infeksi masing-masing 20 ekor, secara oral pada perlakuan a1b0, a1b1 dan a1b2. Persiapan Pencampuran Antibiotika 
H. C. P. Wardhani, W. P. Lokapirnasari, K. Soepranianondo/ Buana Sains Vol 19 No 1 : 61-68

Penimbangan pakan perminggu untuk perlakuan a0b1 dan a1b1 masingmasing 20 ekor ayam petelur. Dosis antibiotika (Virginiamycin) yang diberikan $1 \%$ dari berat pakan. Diperoleh $12 \mathrm{~g} / 5 \mathrm{~kg}$ pakan /minggu. Dicampur hingga homogen.

\section{Persiapan Pencampuran Probiotik}

Pemberian probiotik setiap hari untuk perlakuan P3 dan P4 masingmasing 20 ekor ayam petelur. Dosis probiotik $0,5 \%$ Lactococcus lactis dari konsumsi pakan dan 0,5\% Lactobacillus acidophilus dari konsumsi pakan $10^{7}$ $\mathrm{CFU} / \mathrm{g}$ dicampur dengan $180 \mathrm{ml} /$ ekor/hari.

\section{Hasil dan Pembahasan}

\section{Break Event Point (BEP)}

Break Event Point adalah cara untuk menentukan dan mencari jumlah barang yang harus dijual kepada konsumen dengan tujuan menutupi biaya-biaya yang timbul dan mendapat keuntungan.

$$
\text { BEP Harga }=\frac{\text { Total Biaya }}{\text { Harga Penjualan }} \text { BEP Produksi }=\frac{\text { Total Biaya }}{\text { Total Produksi }}
$$

\begin{tabular}{|c|c|c|}
\hline Hasil tiap perl & BEP Haros & Hasil tiap perlakuan BEI \\
\hline a0b0 & $: \operatorname{Rp} 19.312,34$ & a0b0 : $13,93 \mathrm{~kg}$ \\
\hline $\mathrm{a} 1 \mathrm{~b} 0$ & : Rp 23.946,53 & a1b0 $: 13,94 \mathrm{~kg}$ \\
\hline a0b1 & : Rp 18.481,85 & a0b1 : 14,12 kg \\
\hline a1b1 & $: \operatorname{Rp} 20.731,18$ & a1b1 : 14,11 k \\
\hline $\mathrm{a} 0 \mathrm{~b} 2$ & : Rp 17.587,24 & $\mathrm{a} 0 \mathrm{~b} 2: 14,26 \mathrm{~kg}$ \\
\hline a1b2 & : Rp 18.203,09 & a1b2 :14,36 kg \\
\hline
\end{tabular}

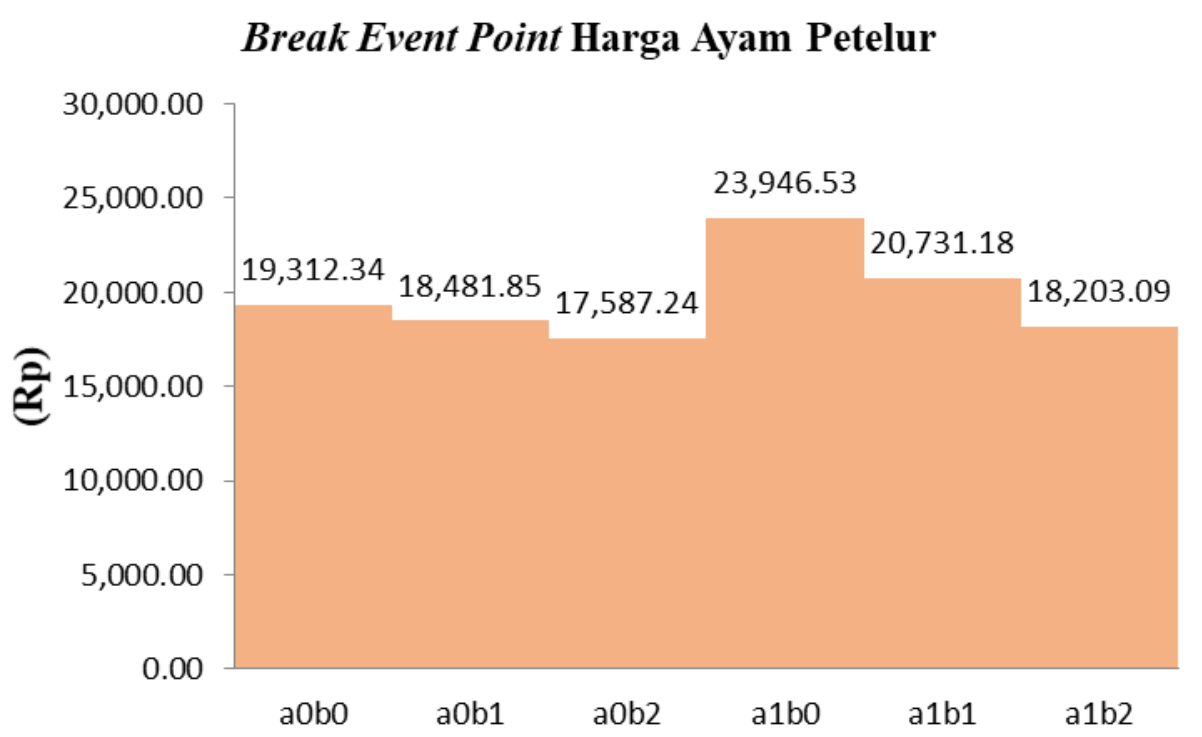

Gambar 1. Grafik Break Event Point (BEP) pada harga ayam petelur 


\section{Break Event Point Produksi Ayam Petelur}

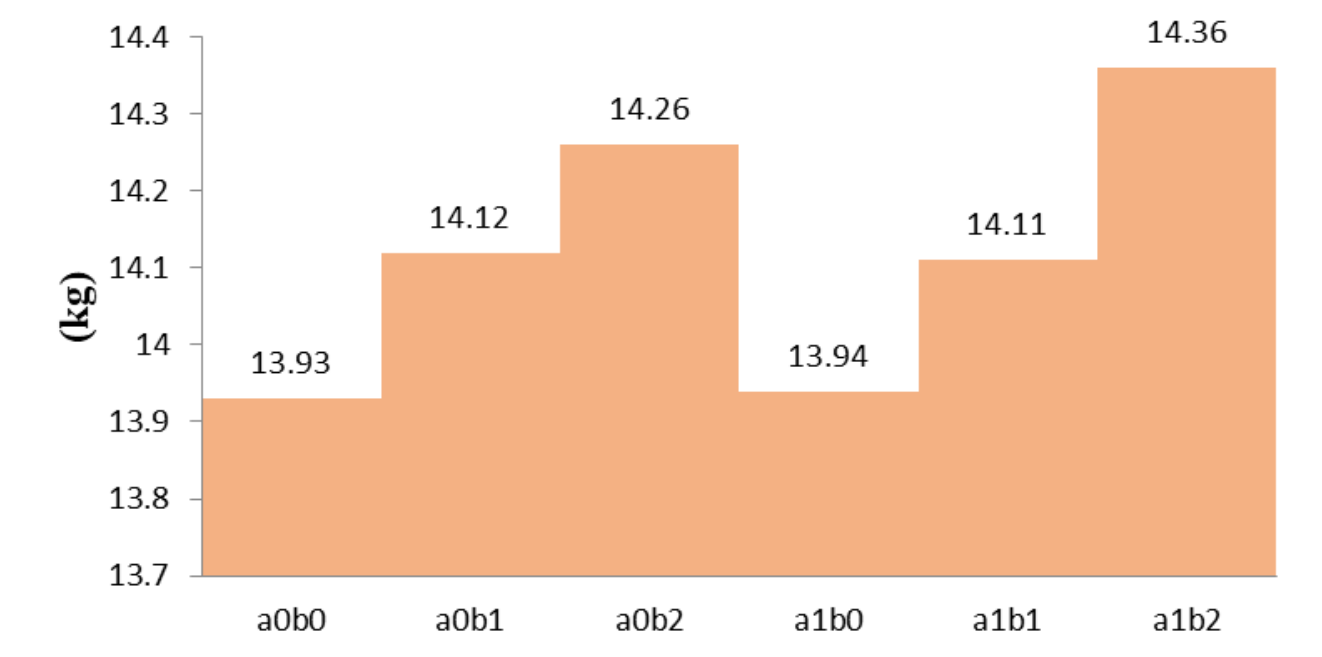

Gambar 2. Grafik Break Event Point (BEP) pada produksi ayam petelur

Dari gambar diatas dapat dengan total biaya. Apabila diperoleh disimpulkan bahwa perlakuan a0b2 hasil $>1$ maka usaha tersebut layak memiliki hasil yang bagus yaitu BEP dikembangkan (Asnidar and Asrida, Harga Rp 17.587,24 dengan BEP 2017).

Produksi 14,26 kg.

\section{Revenue Cost Ratio (R/C Ratio)}

$\mathrm{R} / \mathrm{C}=\underline{\text { Total penerimaan penjualan produk }}$ Total biaya

Revenue Cost Ratio adalah proses

membandingkan total penerimaan Hasil tiap perlakuan :

$\begin{array}{lll}\text { a0b0 }: 1,412 & \text { a1b0 } & : 1,139 \\ \text { a0b1 }: 1,471 & \text { a1b1 } & : 1,312 \\ \text { a0b2 }: 1,543 & \text { a1b2 } & : 1,489\end{array}$

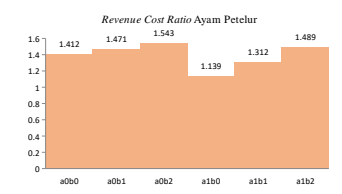

Gambar 3. Grafik Revenue Cost Ratio (R/C Ratio) pada ayam petelur 
H. C. P. Wardhani, W. P. Lokapirnasari, K. Soepranianondo/ Buana Sains Vol 19 No 1 : 61-68

Dari gambar diatas dapat selisih penerimaan dengan pengeluaran disimpulkan bahwa perlakuan a0b2 pertahun, jika nilai yang diperoleh memiliki hasil yang bagus yaitu 1,543 menunjukkan hasil yang lebih sedikit bahwa nilai yang diperoleh $>1$ maka maka hasilnya semakin baik (Riyanto, usaha tersebut layak dikembangkan. 2016).

$$
\mathrm{PP}=\frac{\text { Investasi }}{\text { Cashflow } 1 \text { tahun }}
$$

\section{Payback Period (PP)}

Payback Period adalah perhitungan antara pendapatan yang diperleh antara
a0b0 : 1 year 8 months 7 days
a1b0 : 5 years 5 months 5 days
a0b1 : 1 year 6 months 1 day
a1b1 : 2 years 4 months 3 days
a0b2 : 1 year 3 months 9 days
a1b2 : 1 year 6 months 3 days

\section{Payback Period Ayam Petelur}

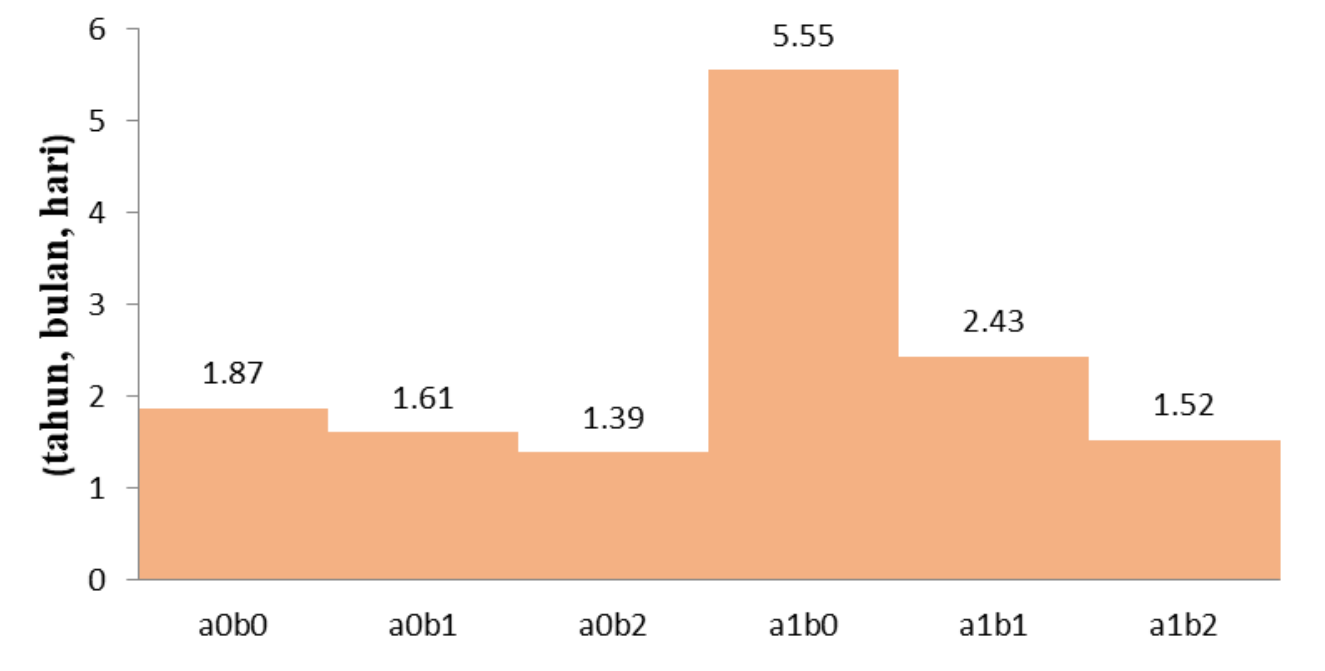

Gambar 4. Grafik Payback Period pada ayam petelur

Gambar diatas menunjukkan bahwa perlakuan a0b2 memiliki hasil yang bagus yaitu $1,39=1$ tahun 3 bulan 9 hari. Perhitungan menggunakan bulan/15hari infeksi. Hasil semakin sedikit maka usaha tersebut layak dikembangkan.

\section{Return On Invesment (ROI)}

Return On Invesment adalah perhitungan yang dilakukan untuk mengukur kemampuan dari sebuah perusahaan secara keseluruhan dalam menghasilkan keuntungan, serta dijadikan sebagai tolak ukur efektifitas sebuah manajemen dalam mengelola investas (Soepranianondo dkk., 2013).

$$
\begin{array}{ll}
\text { ROI }=\frac{\text { Keuntungan bersih }}{\text { Modal usaha }} \times 100 \% \\
\text { a0b0 }: 2,2 & \text { a1b0 }: 0,8 \\
\text { a0b1 :2,6 } & \text { a1b1 }: 1,7 \\
\text { a0b2 }: 3 & \text { a1b2 }: 2,7
\end{array}
$$




\section{Return On Invesment Ayam Petelur}

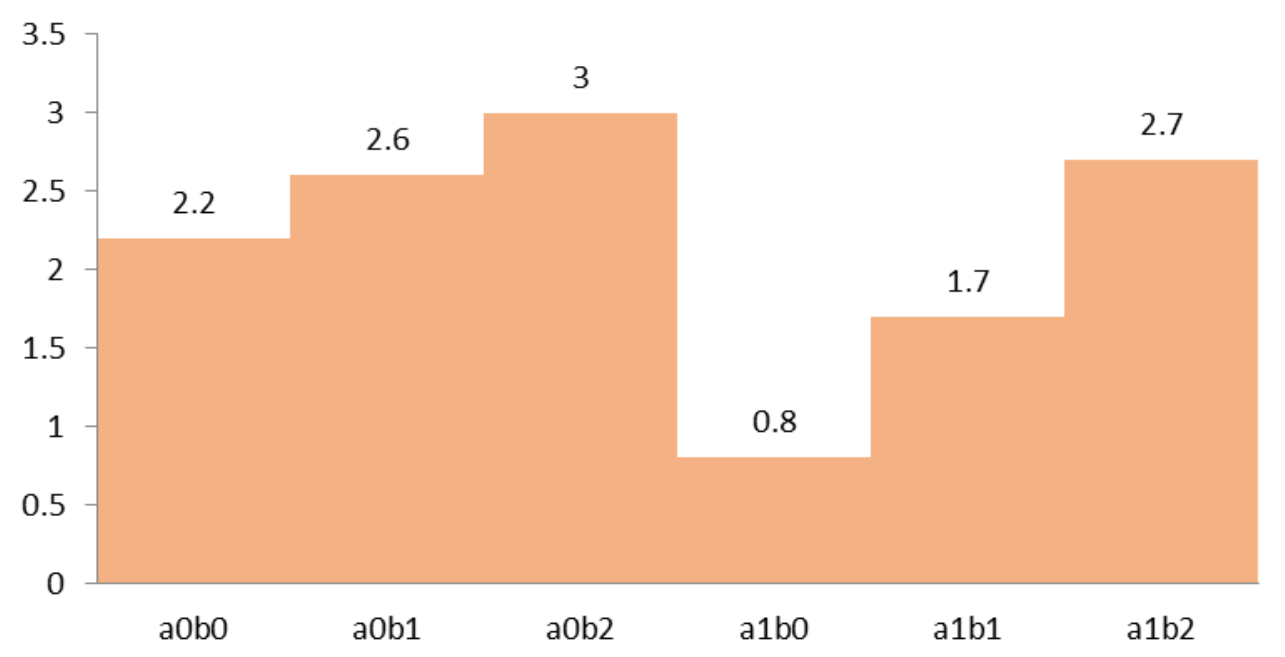

Gambar 4. Grafik Return On Investment (ROI) pada ayam petelur

Pada grafik diatas dapat ditarik kesimpulan bahwa perlakuan a0b1 dan a0b2 memiliki hasil yang bagus yaitu $2,8 \%$. Hasil yang diperoleh semakin tinggi maka semakin bagus.

Berdasarkan hasil penelitin yang dilakukan di Tuban menggunakan sampel ayam petelur dengan mengamati produksi telur dan konsumsi pakan setiap hari selama satu bulan. Analisis usaha mendapatkan hasil yaitu dalam penghitungan Break Event Point, Revenue Cost Ratio, Payback Period dan Return On Invesment. Penghitungan analisis usaha menunjukkan hasil yang bagus pada perlakuan a0b2 (tanpa infeksi + diberi probiotik). Penelitian ini menunjukkan bahwa perlakuan yang diberikan probiotik mampu menjaga produksi telur stabil dan mampu menekan pertumbuhan bakteri penghambat dalam pencernaan sehingga telur yang diproduksi berkualitas baik (Hassan et. al., 2012).

Peternakan ayam petelur merupakan usaha yang berkembang beberapa tahun terakhir, karena meningkatnya permintaan telur ayam sebagai bahan baku pangan untuk kebutuhan masyarakat. Kita tahu protein hewani merupakan protein yang dibutuhkan oleh tubuh salah satunya yaitu terdapat pada telur ayam, sehingga telur ayam lebih diminati karena harga yang terjangkau (Setiawan dkk., 2016).

Eschericia coli adalah flora normal pada saluran pencernaan ayam petelur yang bersifat nonpatogen, tetapi bisa berubah menjadi patogen apabila ayam petelur tersebut mengalami penurunan imun sehingga mengakibatkan ternak mengalami penurunan produksi telur (Arifin dan Pramono, 2014). Penurunan produksi telur mengakibatkan performan ayam petelur buruk, sehingga peternak mengalami kerugian. E.coli dapat ditekan pertumbuhannya dengan pemberian antibiotika pada pakan, akan tetapi penggunaan antibiotika jangka panjang sudah dilarang pemberiannya pada pakan ayam dikarenakan residu pada hasil ternak yang berdampak buruk untuk konsumen (Suryani dkk., 2014).

Probiotik merupakan alternatif yang dapat dipilih sebagai pengganti antibiotika pada pakan, pemberian probiotik dapat diberikan melalui pakan dan minum. Probiotik kombinasi yang 
digunakan adalah Lactococcus lactis dan Lactobacillus acidophilus merupakan probiotik yang baik untuk pencernaan dan mampu meningkatkan daya serap sehingga nutrisi yang diperolah dari pakan mampu terserap sempurna (Enby et al., 2012). Penyerapan yang sempurna mampu meningkatkan sistem imun sehingga ayam petelur tidak mudah sakit akibat bakteri patogen. Probiotik mampu sebagai pengatur keseimbangan mikroorganisme pada saluran pencernaan dan memiliki sifat tidak patogen sehingga aman untuk dikonsumsi ayam petelur jangka panjang (Garabal et al., 2007).

Penelitian ini dilakukan karena pemakaian antibiotika pada pakan sebagai tambahan untuk kesehatan ternak berdampak buruk untuk kesehatan konsumen, menyebabkan efek seperti mual dan bahkan resisten terhadap antibiotika tertentu. Hal ini bisa terjadi karena pemberian antibiotika pada pakan tidak diawasi oleh dokter hewan, sehingga pemberiannya tidak sesuai dosis. Kejadian ini menyebabkan saya melakukan eksperimen pemberian probiotik kombinasi Lactococcus lactis dan Lactobacillus acidophilus sebagai pengganti antibiotika. Peran probiotik sendiri hampir sama dengan antibiotika yaitu menekan pertumbuhan bakteri patogen seperti Eschericia coli. Keunggulan probiotik mampu menjaga kesehatan pencernaan dan mampu meningkatkan penyerapan nutrisi sehingga kebutuhan produksi dan kebutuhan tubuh terpenuhi. Menjadikan peternak lebih efisien dalam pemberian pakan dan produksi telur stabil, mengakibatkan keuntungan yang lebih dan menyehatkan konsumen.

\section{Kesimpulan}

Penambahan probiotik kombinasi Lactococcus lactis dan Lactobacillus acidophilus melalui air minum pada analisis usaha dapat menurunkan Break Event Point harga, meningkatkan Break Event Point produksi, meningkatkan Revenue Cost Ratio dan menurunkan Payback Period,serta mampu menggantikan peran antibiotika sebagai Antibiotic Growth Promoter (AGP) dan menjaga ayam petelur agar tidak mudah terinfeksi.

\section{Daftar Pustaka}

Arifin, M dan V.J Pramono. 2014. Pengaruh Pemberian Sinbiotik Sebagai Alternatif Pengganti Antibiotic Growth Promoter Terhadap Pertumbuhan dan Ukuran Vili Usus Ayam Broiler. Urnal Sain Veteriner. ISSN : 0126-0421.

Asnidar dan Asrida. 2017. Analisis Kelayakan Usaha Home Industry Kerupuk Opak Di Desa Paloh Meunasah Dayah Kecamatan Muara Satu Kabupaten Aceh Utara. Jurnal S. Pertanian 1 (1) : 39-47.

Barton, M.D. 2000. Antibiotic use in animal feed and its impact on human health. Nutr Res Rev. 13(2):119.

Choiriyah, V.U., AR.. M.D dan R.R. Hidayat. Analisis Break Event Point Sebagai Alat Perencanaan Penjualan Pada Tingkat Laba yang Diharapkan. Jurnal Administrasi Bisnis. Vol. 35 No. 1.

Enby, H.M., Maher, A.H., Birte, S., Susanne, J and J.S. Dirk. 2012. Probiotic Lactobacillus acidophilus NCFM and Bifidobacterium animalis subsp lactis Bl-04 interactions with prebiotic carbohydrates using differential proteomics and protein characterization. Kgs. Lyngby: Technical University of Denmark (DTU). 
H. C. P. Wardhani, W. P. Lokapirnasari, K. Soepranianondo/ Buana Sains Vol 19 No 1 : 61-68

Garabal, J.I., Alonso, P.R., and J.A. Centeno.2007. Characterization of lactic acid bacteria i o ed om w ow' $\mathrm{mi} \mathrm{k}$ hee e currently produced in Galicia (NW Spain). Swiss Soc. of Food Sci. and Technol.

Hassan, E.R., Mahgoob, K.M., Zaenab, Kh.M.E., Girh, AM.S., and H.M. Mekky. 2012. Comparative Studies between the Effects of Antibiotic (Oxytetracycline); Probiotic and Acidifier on E. coli Infection and Immune Response in Broiler Chickens. Jurnal of American Science, 2012;8(4).

Jamin, F., Abrar, M., Dewi, M., Yanrivina, S.V.S., Fakhrurrazi., Manaf, Z.H., dan Syafruddin. 2015. Infeksi Escherichia coli Pada Anak Ayam Kampung (Gallus domesticus) di Pasar Lambaro Aceh Besar Jurnal Medika Veterineria. Vol. 9 No. 1.

Nuryhev, M.Z., Stoyanova, L.G and A.I Netrosov. 2016. New Probiotic Culture of Lactococcus lactis ssp. Lactis: Effective Opportunities and Prospects. Jurnal of Microbial \& Biochemical Technology.

Pertami S.D., Pancasiyauar M., Irasari S.A., Rahardjo and M.B., Wasilah. 2013. Lactobacillus acidophilus Probiotic Inhibits the Growth of Candida albicans. Jurnal of Dentistry Indonesia Vol. 20 No.3 Hal. 64-67.

Riyanto B. 2011. Dasar-dasar Pembelajaran Perusahaan, BPFEYogyakarta. Yogyakarta.

Setiawan, T., Afnan, R., dan N. Ulupi. 2016. Performa Produksi dan Kualitas Telur Ayam Petelur pada Sistem Litter dan Dage dengan Suhu Kandang Berdeda. Fakultas Peternakan Institup Pertanian Bogor. Jurnal Ilmu Produksi dan
Teknologi Hasil Peternakan. Vol. 02 No. 1 Hlm: 197-203.

Soepranianondo, K., R. Sidik, D.S. Nazar, S. Hidanah, Pratisto dan S.H. Warsito. 2013. Buku Ajar Kewirausahaan. Airlangga Univerity Press. Surabaya. 192-197.

Subekti, E dan D. Hastuti. 2015. Pengaruh Penambahan Probiotik Herbal Pada Ransum Terhadap Performent Itik Pedaging. Program Studi Agribisnis Universitas Wahid Hasyim Semarang.

Supriatna, I., Hismayasari, I.B., Bidiadnyani, I.G.A., Sayuti, M., dan A. Yani. 2016. Analisis Karakteristik Bakteri Probiotik. Politeknik Kelautan dan Perikanan Sorong. Jurnal Airaha. Vol 5. No 2 : 130-132.

Suryani, A.E., Karimy, M.F., Istiqomah, L., Sofyan, A., Herdian, H., dan M.H. Wibowo. 2014. Prevalensi Kolibasilosis Pada Ayam Broiler Yang Diinfeksi Escherichia coli Dengan Pemberian Bioaditif, Probiotik dan Antibiotik. Laboratorium Mikrobiologi Fakultas Kedokteran Hewan Universitas Gadjah Mada. Bagian Pakan dan Nutrisi Ternak. Vol. 17. No. 2. 